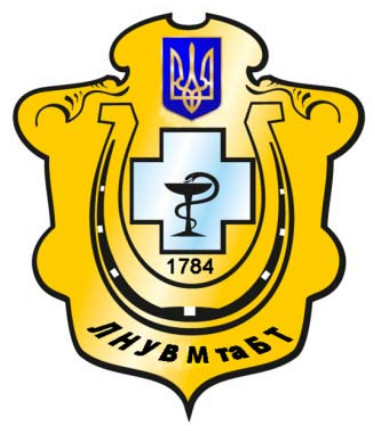

Науковий вісник Львівського національного університету ветеринарної медицини та біотехнологій імені С.3. Гжицького

Scientific Messenger of Lviv National University of Veterinary Medicine and Biotechnologies named after S.Z. Gzhytskyj

doi:10.15421/nvlvet6818

ISSN 2413-5550 print

ISSN 2518-1327 online

$\underline{\text { http://nvlvet.com.ua/ }}$

УДК 621.37:637.142

\title{
Вплив імпульсного електромагнітного поля на життєздатність Escherichia coli в модельному розчині молочної сироватки
}

\author{
Р.С. Святненко, А.І. Маринін, О.В. Кочубей-Литвиненко, В.Б. Захаревич \\ Svyatnenko@i.ua, andrii_marynin@ukr.net
}

Національний університет харчових технологій, вул. Володимирська, 68, м. Київ, 01601, Украӥна

\begin{abstract}
Важливим показником мікробіологічної безпечності та якості, а також рівня санітарно-гігієнічних умов виробництва $є$ бактерії групи кишкових паличок. При перевищенні допустимого титру иі мікроорганізми можуть спричиняти псування готового продукту $і$ навіть харчові отруєння. В проблемно науково-дослідній лабораторії Начіонального університету харчових технологій були проведені експерементальні дослідження з метою вивчення дії впливу імпульсних електромагнітних полів на ентеробактерії, а саме культури Escherichia coli в модельному розчині молочної сироватки.

При проведенні досліджень використовувалася експериментальна установка, яка розроблена фахівиями в НТУ «Харківський Політехнічний Інститут». Для диференціаиії Escherichia coli використовувалося середовище Ендо, у якому иі бактерії давали характерний ріст у вигляді колоній червоного кольору з метелевим блиском. Модельні розчини молочної сироватки обробляли при напрузі $15 \ldots 30 \mathrm{\kappa Bm} / \mathrm{cm}^{3}$, з тривалістю обробки $10 \ldots 20$ с. Результати мікробіологічних досліджень модельного розчину сироватки молочної підтверджені комунальним підприємством «Санепідсервісом» м. Харкова.

Встановлено, що обробка електромагнітними імпульсами з напругою $30 \mathrm{\kappa Bm} / \mathrm{cm}^{3}$ протягом 20 с є найбільш ефективною, оскільки спостерігається повна інактивація клітини Escherichia coli внесеної до молочної сироватки.

Доведено можливість здійснення теплового оброблення молочної сироватки за рахунок нетеплових ефектів, щзо виникають за імпульсної дії електричних полів. Відкрито перспективи використання вітчизняних ІЕП-установок при первинному обробленні молочної сироватки з метою знищення мікроорганізмів.

Ключові слова: імпульсні електромагнітні поля, сироватка молочна, культура Escherichia coli.
\end{abstract}

\section{Влияние импульсного электромагнитного поля на жизнеспособность Escherichia coli в модельном растворе молочной сыворотки}

\author{
Р.С. Святненко, А.И. Маринин, А.В. Кочубей-Литвиненко, В.Б. Захаревич \\ Svyatnenko@i.ua, andrii_marynin@ukr.net
}

Национальный университет пищевых технологий,

ул. Владимирская, 68, г. Киев, 01601, Украина

\begin{abstract}
Важным показателем микробиологической безопасности и качества, а также уровня санитарно-гигиенических условий производства являются бактерии группы кишечных палочек. При превышении допустимого титра эти микроорганизмы могут вызывать порчу готового продукта и даже пищевые отравления. В Проблемно научно-исследовательской лаборатории Национального университета пищевых технологий были проведены экспериментальные исследования с иелью изучения действия влияния импульсных электромагнитных полей на энтеробактерии, а именно культуры Escherichia coli 6 модельном растворе молочной сыворотки.

При проведении исследований использовалась экспериментальная установка, разработанная специалистами в НТУ «Харьковский Политехнический Институт». Для дифференциации Escherichia coli использовалась среда Эндо, на которую эти бактерии давали характерный рост в виде колоний красного ивета с металическим блеском. Модельные растворы молочной сыворотки обрабатывали при напряжении $15 \ldots 30 \mathrm{kBm} / \mathrm{cm}^{3}$, с продолжительностью обработки 10 ... $20 \mathrm{c.}$ Ре-
\end{abstract}

\section{Citation:}

Svyatnenko, R., Marynin, A., Kochubej-Litvinenko, O., Zakharevych, V. (2016). Impact of pulsed electromagnetic field on Escherichia coli vitality in model solution of milk serum. Scientific Messenger LNUVMBT named after S.Z. Gzhytskyj, 18, 2(68), 92-94. 
зультаты микробиологических исследований модельного раствора сыворотки молочной, подтвержденные коммунальньм предприятием «Санепидсервисом» г.Харькова. При исследованиях установлено, что обработка электромагнитньми импульсами с напряжением $30 \mathrm{\kappa Bm} / \mathrm{cm}^{3}$ в течение 20 с является наиболее эффективной, поскольку наблюдается полная инактивация клеток Escherichia coli, внесённых в молочную сыворотку.

Доказана возможность осуществления тепловой обработки молочной сыворотки за счёт нетепловых эффектов, возникающих при импульсном воздействии электрических полей. Открыто перспективы использования отечественных ИЭПустановок при первичной обработке молочной сыворотки с иелью уничтожения микроорганизмов.

Ключевые слова: импульсные электромагнитные поля, сыворотка молочная, культура Escherichia coli.

\title{
Impact of pulsed electromagnetic field on Escherichia coli vitality in model solution of milk serum
}

\author{
R. Svyatnenko, A. Marynin, O. Kochubej-Litvinenko, V. Zakharevych \\ Svyatnenko@i.ua, andrii_marynin@ukr.net \\ National University of Food Technologies, \\ Volodymyrska Str., 68, Kyiv, 01601, Ukraine
}

An important indicator of microbiological safety and quality, and production sanitary conditions are bacteria of Escherichia coli. At excess of acceptable titer these microorganisms can cause to damage the finished product and even food poisoning.

We investigated the impact of a pulsed electromagnetic field (PEF) treatment on the vitality of Escherichia coli in a model solution of milk serum in the Problematic Science Research Laboratory of National University of Food Technologies.

The studies were conducted using experimental installation developed of National Technical University "Kharkiv Polytechnic Institute». For the differentiation of Escherichia coli was used Endo medium where the bacteria growth appears in the form of red colonies with metal shine. Model solutions of whey treated at voltage of $15 \ldots 30 \mathrm{~kW} / \mathrm{cm} 3$, treatment time 10 ... $20 \mathrm{~s}$. Research results of milk serum model solution confirmed by public utility «Sanepidservisom» Kharkiv.

It was determined that PEF treatments with voltage of $10 \mathrm{~kW} / \mathrm{cm} 3$ during $20 \mathrm{~s}$ is the most effective, because there was complete inactivation of Escherichia coli cells inoculated to milk serum. It was proved the possibility of heat treatment of milk serum by nonthermal effects generated by the pulse action of electrical fields. It was showed the perspective of using local PEF equipment at primary treatment of milk serum for microbial inactivation.

Key words: pulsed electromagnetic fields, milk serum, culture of Escherichia coli.

\section{Вступ}

Останніми роками інтенсивно розвивається напрям в харчовій технології - обробка харчових продуктів, сировини і промислових мікроорганізмів нетепловими методами, зокрема імпульсними електромагнітними полями.

Електромагнітні поля є важливим і ефективним фактором інтенсифікації багатьох технологічних, в тому числі біотехнологічних процесів (Barsotti and Cheftel, 1999).

Сутність реалізації технології ІЕП в харчовій промисловості полягає в тому, що імпульсні електричні поля в діапазоні напруги $5 \ldots 100$ кВ/см ${ }^{3}$ при тривалості дії в кілька десятків мікро або наносекунд викликають мікробну інактивацію за температур нижчих, ніж ті, що використовуються при тепловій обробці. При цьому оброблення IЕП дозволяє уникнути чи максимально зменшити небажані зміни органолептичних показників, біологічної та харчової цінності продуктів (Guli et al., 1994; Barbosa-Canovas et al., 1999).

Вітчизняний і закордонний досвід вказує на широке використання IЕП в харчовій технології. Проте багато питань, пов'язаних 3 механізмом дії IЕП на живі клітини, залишаються нез'ясованими, що сповільнює широке використання в промисловості.

Метою роботи було вивчення дії впливу IЕП на ентеробактерії, а саме культури Escherichia coli в модельному розчині молочної сироватки.

\section{Матеріал і методи досліджень}

Як об'єкт досліджень використовували культури Escherichia coli на основі модельних розчинів сироватки молочної.

Escherichia coli - вид грамнегативних паличкоподібних бактерій, які завжди міститься в кишечнику людини і тварин. Більшість штамів E. coli є нешкідливими, проте серотип О157: Н7 може викликати важкі харчові отруєння у людей (Bach et al., 2002). Клітини $E$. coli паличкоподібні, зі злегка закругленими кінцями, розміром $0,4-0,8 \times 1-3$ мкм, обсяг клітини становить близько 0,6-0,7 мкм³. Оптимальне зростання досягається культурами E. coli при температурі $37^{\circ} \mathrm{C}$, деякі штами можуть ділитися при температурах до $49^{\circ} \mathrm{C}$ (Bach et al., 2002). E. coli широко використовується в генетичних дослідженнях прокаріот, завдяки зручності іiі культивування, і тому вивчена краще за всі інші мікроорганізми.

При проведенні досліджень використовувалася експериментальна установка, яка розроблена в НТУ «Харківський Політехнічний Інститут» (Boyko, 2001).

3 метою вивчення впливу електромагнітних полів на життєздатність культуру E. coli готували модельні розчини молочної сироватки таким чином. Молочну сироватку 3-під сиру кисломолочного стерилізували в автоклаві при температурі $\mathrm{t}=119{ }^{\circ} \mathrm{C}$ протягом двох годин. В стерилізовану сироватку вносили необхідну кількість бактерій $E$. coli, щоб отримати розведення $10^{6}$ та $10^{8} \mathrm{KOУ} / \mathrm{cm}^{3}$. Потім до стерильної камери закритого типу об'ємом $150 \mathrm{~cm}^{3}$ вносили модельні роз- 
чини молочної сироватки. Після приєднання робочої камери до електродної системи генератора імпульсних напруг, при режимах обробки $15 \ldots 30 \mathrm{\kappa BT} / \mathrm{cm}^{3}$ впродовж $10 \ldots 20$ с проводили обробку через іскровий розрядний проміжок 0,01мм. Напругу дії IЕП контролювали осцилографом.

Для диференціації E.coli використовувалося середовище Ендо, на якому ці бактерії давали характерний ріст у вигляді колоній червоного кольору з металевим блиском.

\section{Результати та їх обговорення}

Після електромагнітного оброблення модельних розчинів в мікробіологічній лабораторії відбувався кількісний підрахунок бактерій, що вижили, шляхом прямого підрахунку колоній на щільному поживному середовищі (ГОСТ 26670-91).

Результати проведених досліджень 3 вивчення вПливу IEП на життездатність E. coli в модельному розчині молочної сироватки наведено в табл. 1.

Одержані експериментальні дані показують, що із збільшенням напруги та тривалості оброблення відбувається істотне зниження кількості мікроорганізмів в усіх зразках. Зниження життєдіяльності мікроорганізмів, на наш погляд, можна пояснити комплексним впливом виникаючих при IЕП обробці потужних електромагнітних хвиль та нетеплового ефекту зростання температури.

Найбільш інтенсивний вплив IЕП на зразки спостерігається під час оброблення протягом 20 с 3 напругою 30 кВт/см ${ }^{3}$ оскільки в них повністю відсутні патогенні мікроорганізми.

Табличя 1

Показники обробленого модельного розчину молочної сироватки електромагнітними полями при різних режимах

\begin{tabular}{|c|c|c|c|}
\hline \multirow{2}{*}{$\begin{array}{c}\text { Модельний розчин молочної сироват- } \\
\text { ки з розведенням КУО/ } \mathrm{cm}^{3}\end{array}$} & \multicolumn{2}{|c|}{ Режим оброблення } & \multirow{2}{*}{$\begin{array}{c}\text { Кількість мікроорганізмів } \\
\text { КУО/см } \\
\end{array}$} \\
\hline & Напруга, кВт/см ${ }^{3}$ & Час оброблення, с & \\
\hline \multirow[t]{8}{*}{ 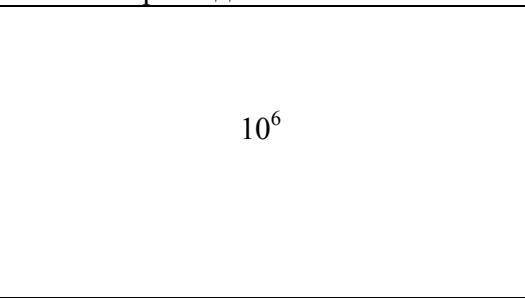 } & \multirow{4}{*}{$15 \kappa \mathrm{BT} / \mathrm{cm}^{3}$} & 0 & $10^{6}$ \\
\hline & & 10 & 100 \\
\hline & & 15 & 60 \\
\hline & & 20 & 40 \\
\hline & \multirow{4}{*}{$30 \kappa B \mathrm{~T} / \mathrm{cm}^{3}$} & 0 & $10^{6}$ \\
\hline & & 10 & 30 \\
\hline & & 15 & 17 \\
\hline & & 20 & відсутні \\
\hline \multirow{8}{*}{$10^{8}$} & \multirow{4}{*}{15 кВт/см ${ }^{3}$} & 0 & $10^{8}$ \\
\hline & & 10 & 80 \\
\hline & & 15 & 50 \\
\hline & & 20 & 25 \\
\hline & \multirow{4}{*}{$30 \kappa B \mathrm{~T} / \mathrm{cm}^{3}$} & 0 & $10^{8}$ \\
\hline & & 10 & 20 \\
\hline & & 15 & 15 \\
\hline & & 20 & відсутні \\
\hline
\end{tabular}

Також слід відмітити, що за допомогою режиму оброблення незбираного молока відбувалася інактивація ферменту фосфатази, що є обов'язковою умовою ефективності пастеризації молочної сироватки.

\section{Висновки}

Доведено можливість здійснення теплового оброблення молочної сироватки за рахунок нетеплових ефектів, що виникають за імпульсної дії електричних полів. Відкрито перспективи використання вітчизняних ІЕП-установок при первинному обробленні молочної сировини.

Дані результати відкривають перспективи розвитку напряму створення нових методів обробки харчових продуктів за допомогою IЕП з покращеними характеристиками. Створені установки та методики направлені для з'ясування механізмів дії факторів IЕП, в подальшій розробці концепції, теорії ІЕП обробки продуктів.

\section{Бібліографічні посилання}

Barsotti, L., Cheftel, J.C. (1999). Food processing by pulsed electric fields. II. Biological aspects. Food Review International. 15(2), 181-213.

Guli, L., Lebovka, S.N., Mank, I.V., Kupchyk, M.P, Bashal, M.I., Matvijenko, A.B., Panchenko, A.H. (1994). Pryncypy elektrotehniky obrobky harchovyh produktiv i materialiv. Naukovo-praktychnyj. Ukr INTEI, Kyi'v. 10, 15-18 (in Ukrainian).

Barbosa-Canovas, G., Gingora-Nieto, M.M., Pothakamury, U.R., Preservation, G., Swanson, B.G. (1998). Preservation of Foods with Pulsed Electric Fields. London: Academic Press.

Bach, S.J., McAllister, T.A., Veira, D.M., Gannon, V.P.J., Holley R.A. (2002). Transmission and control of Escherichia coli O157:H7. Canadian Journal of Animal Science. 82, 475-490.

Boyko, N.I. (2001). Vysokovol'tnye apparaty i tehnologii na osnove kompleksa vysokovol'tnyh impul'snyh vozdejstvij. Visnyk NTU «HPI». 16, 11-16 (in Russian).

Стаття надійшла до редакичї 1.09.2016 